\title{
Hemotropic mycoplasmas in naturally infected cats in Northeastern Brazil
}

\author{
Micoplasmas hemotróficos em gatos naturalmente infectados no Nordeste do Brasil \\ Alexandre Dias Munhoz ${ }^{1 *}$; Izabela Garcia Pinto Coelho Simóes ${ }^{1}$; Ana Paula Fernandes Calazans ${ }^{1}$; Ludimila Santos Macedo; \\ Rebeca Dálety Santos Cruz ${ }^{1}$; Luciana Carvalho Lacerda ${ }^{1}$; Roueda Abou Said ${ }^{1}$; Marcos Rogério André ${ }^{2}$ \\ ${ }^{1}$ Departamento de Ciências Agrárias e Ambientais, Universidade Estadual de Santa Cruz - UESC, Campus Soane Nazaré de \\ Andrade, Ilhéus, BA, Brasil \\ ${ }^{2}$ Departamento de Patologia Animal, Universidade Estadual Júlio de Mesquita Filho - UNESP, Jaboticabal, SP, Brasil
}

Received April 25, 2018

Accepted September 05, 2018

\begin{abstract}
This study aimed to determine the prevalence, factors associated, laboratory findings (with and without coinfection by retroviruses) among naturally infected cats by hemoplasmas in northeastern Brazil. For convenience, 200 domesticated and healthy cats were selected. Blood samples were taken to perform complete blood counts, serum biochemical, immunochromatography tests and nPCR for FIV and FeLV, and PCR for hemoplasma recognition. An interview was conducted to determine the factors associated with hemoplasmas. A total of 71/200 (35.5\%) cats were positive for at least one hemoplasma species. Isolated infections were observed in 12,5\% for 'Candidatus Mycoplasma haemominutum', 12\% for Mycoplasma haemofelis and 3\% for 'Candidatus Mycoplasma turicensis'. Regarding copositivity, 2\% of the animals were positive for $M$. haemofelis and 'Candidatus Mycoplasma haemominutum', 1.5\% for M. haemofelis and 'Candidatus Mycoplasma turicensis', and 4.5\% for 'Candidatus Mycoplasma haemominutum' and 'Candidatus Mycoplasma turicensis'. No clinical and laboratory changes were observed in the animals that were concomitantly positive for retroviruses and hemoplasmas. Periurban region cats were more likely to be infected by $M$. haemofelis, while contact with other cats and infection by 'Candidatus Mycoplasma turicensis' were associated with 'Candidatus Mycoplasma haemominutum'. This study indicates that infection by hemoplasmas is a common find in cats from northeastern Brazil.
\end{abstract}

Keywords: Hemoplasmas, Mycoplasma haemofelis, 'Candidatus Mycoplasma haemomominutum', 'Candidatus Mycoplasma turicensis', retrovirus.

\section{Resumo}

Objetivou-se com este estudo determinar a prevalência, fatores associados, achados laboratoriais (com e sem coinfecção com retrovírus) em gatos naturalmente infectados por hemoplasmas no Nordeste do Brasil. Selecionou-se, por conveniência, 200 gatos domiciliados, hígidos, sendo colhidas amostras de sangue para realização do hemograma, bioquímica sérica, imunocromatografia e nested-PCR para FIV e FeLV, e PCR para identificação dos hemoplasmas. Uma entrevista foi realizada para determinação dos fatores associados aos hemoplasmas. A frequência de positividade foi de 35,5\% (71/200). Infecçóes isoladas foram observadas em 12,5\% dos animais para 'Candidatus Mycoplasma haemominutum', 12\% para Mycoplasma haemofelis e 3\% para 'Candidatus Mycoplasma turicensis'. Quanto a co-positividades, 2\% dos animais foram positivos para $M$. haemofelis e 'Candidatus Mycoplasma haemominutum', 1,5\% foram positivos para M. haemofelis e 'Candidatus Mycoplasma turicensis', e 4,5\% foram positivos para 'Candidatus Mycoplasma haemominutum' e 'Candidatus Mycoplasma turicensis'. Não foram observadas alteraçóes clínicas ou laboratoriais nos animais positivos para retrovírus e hemoplasmas, concomitantemente. A regiáo periurbana foi identificada como fator de risco associado a M. haemofelis. Enquanto o contato com outros gatos e a infecção por 'Candidatus Mycoplasma turicensis' foi associado à 'Candidatus Mycoplasma haemominutum'. Este estudo indica que a presença dos agentes da micoplasmose hemotrópica felina é comum no Nordeste brasileiro.

Palavras-chave: Hemoplasmas, Mycoplasma haemofelis, 'Candidatus Mycoplasma haemomominutum', 'Candidatus Mycoplasma turicensis', retrovírus.

\footnotetext{
*Corresponding author: Alexandre Dias Munhoz. Departamento de Ciências Agrárias e Ambientais, Universidade Estadual de Santa Cruz - UESC, Campus Soane Nazaré de Andrade, Rodovia Jorge Amado, Km 16, CEP 45662-900,

Salobrinho, Ilhéus, BA, Brasil. e-mail: munhoz@uesc.br
} 


\section{Introduction}

Mycoplasma haemofelis, 'Candidatus Mycoplasma haemominutum' ('Ca. M. haemominutum') and ' $\mathrm{C} a$. M. turicensis' are Gram-negative bacteria that act as parasites on the surface of cats' red blood cells. These agents are called hemotropic mycoplasmas or feline hemoplasmas and can cause hemotropic mycoplasmosis, in which the main clinical manifestation is anemia (BARKER \& TASKER, 2013).

Infection by $M$. haemofelis tends to be more pathogenic, especially in the acute phase of the disease, with massive parasitemia in red blood cells that leads to severe hemolytic anemia (BERENT et al., 1998). Even if this hemoplasma is not the most prevalent type, it will be present in animals with clinical signs or more severe laboratory abnormalities (JENSEN et al., 2001; TASKER et al., 2004). However, ' $\mathrm{Ca}$. M. haemominutum' has been shown to be non-pathogenetic (FOLEY et al., 1998; MACIEIRA et al., 2008), except in situations of coinfection (SANTOS et al., 2014). 'Ca. M. turicensis' can give rise to moderate to severe anemia (WILLI et al., 2005), although correlation between this agent and anemia is not always possible, since isolated infections are uncommon (PETERS et al., 2008; SYKES et. al., 2008).

The simplest method for establishing the diagnosis of hemoplasmas is through examining blood smears. However, this technique presents low sensitivity and specificity (MACIEIRA et al., 2008), especially in asymptomatic cats (PETERS et al., 2008; TASKER et al., 2003; JENSEN et al., 2001). This, together with the impossibility of determining the hemoplasma species, makes use of more sensitive tools such as the polymerase chain reaction (PCR) (FOLEY et al., 1998), real-time PCR (SYKES et al., 2007) and southern blotting (MACIEIRA et al., 2009) essential for detection and differentiation of hemoplasmas, both for clinical and for epidemiological purposes. This is especially so in cases of very low parasitemia.

It is possible that the primary vectors of the infection are hematophagous arthropods, such as fleas and ticks (WOODS et al., 2005; WILLI et al, 2006a; WILLI et al., 2007a). In addition, other forms of transmission involving animal exposure to contaminated blood have been described, such as blood transfusion procedures (HACKETT et al., 2006) or fights with biting (GRINDEM et al., 1990). Vertical transmission has been suggested, but it has not been definitely demonstrated (HORNOK et al., 2011; PENTECOST et al., 2012).

The risk factors commonly associated with infection are: age (TASKER et al., 2004; SANTOS et al., 2014; GHAZISAEEDI et al., 2014), sex (males) (TASKER et al., 2004; WILLI et al., 2006a,b; GHAZISAEEDI et al., 2014), breed (MACIEIRA et al., 2008), access to streets (SANTOS et al., 2014; INOKUMA et al., 2004) and infection by the feline immunodeficiency virus (FIV) and feline leukemia virus (FeLV)(MACIEIRA et al., 2008; SYKES et al., 2008; TANAHARA et al., 2010).

FIV and FeLV infection can cause immunosuppression in hosts (TOMPKINS et al., 1991; GREGGS et al., 2011), resulting in some cases to an increase in hemoplasma multiplication, with a greater chance of detecting them in PCR (TANAHARA et al., 2010), making the animal susceptible to develop acute hemotropic mycoplasmosis.

Hemoplasmas present great variations in prevalence found (BARKER \& TASKER, 2013) and cosmopolitan distribution (FOLEY et al., 1998; TASKER et al., 2003, 2004; WILLI et al., 2006a, b; INOKUMA et al., 2004; GHAZISAEEDI et al., 2014). They have already been reported in cats from different regions of Brazil (MACIEIRA et al., 2008; BRAGA et al., 2012; DE BORTOLI et al., 2012; MICELI et al., 2013; SANTIS et al., 2014; ANDRÉ et al., 2014; SANTOS et al., 2014). However, in the northeastern region of the country, there are no records of concomitant infection between hemoplasmas and retroviruses, or of the effect of infection on the hematological parameters of cats.

Thus, this study aimed to determine the prevalence, laboratory findings (with and without coinfection by retrovirus) and factors associated among naturally infected cats by hemoplasmas in the state of Bahia, northeastern Brazil.

\section{Materials and Methods}

\section{Study location and sampling design}

The study was conducted from February 2012 to April 2013 in the municipalities of Ilhéus (latitude 14047"S; longitude 39002"W) and Itabuna (14047" $\left.\mathrm{S} ; 39^{\circ} 16^{\prime \prime} \mathrm{W}\right)$, in the microregion of Ilhéus-Itabuna, Bahia, northeastern Brazil. Through non-probability sampling, 200 cat owners were selected from the records of veterinary clinics in the region. Blood samples were collected from these animals in their homes. The inclusion criteria were: 1) it needed to be apparently healthy cats (PERSICHETTI et al., 2016), i.e., clinical examination did not show any abnormalities suggestive of systemic disease such as prostration, vomiting, diarrhea, weight loss, nasal secretion, murmurious, fever or neoplasia (COLLADO et al., 2012) and 2) it had to be 6 months of age or over. The project received protocol no. 011/12 from our institution's Ethics Committee on Animal Use (CEUA-UESC).

\section{Sampling}

After obtaining prior consent from the owners, the animals were physically restrained, and about $4 \mathrm{~mL}$ of blood were collected. From this, $2 \mathrm{~mL}$ was placed in a tube with EDTA, in order to perform a complete blood count and extract genomic DNA, and $2 \mathrm{~mL}$ was placed in a tube without anticoagulant, in order to obtain blood serum for serum biochemical and serological tests for FIV and FeLV. After this, a semi-structured interview was conducted to gather information on the habits and handling of the animals. To evaluate factors associated with hemoplasmas positivity, a semi-structured interview was conducted for each sampled cat. The data recorded included: gender (male/female), age (between 6 months up to 12 months age vs $>1$ year old), pure breed (yes/no), castrated (yes/no), fight history (yes/no), presence of fleas during the interview (yes/no), living in apartment (yes/no), housing (indoors/outdoors) living in periurban area (yes/no), contact with other cats (yes/no), and FIV and/or FeLV status (yes/no). 


\section{Complete blood count and serum biochemical tests}

The animals' complete blood counts were determined using an automated hematological counter (ABX VET, Horiba ${ }^{\mathrm{rm}}$, Montpellier, France). Blood smears were fixed in methanol for five minutes and stained by means of the Giemsa method (Merck S/A, Rio de Janeiro, Rio de Janeiro, Brazil). They were used to determine the specific leukocyte count and conduct morphological evaluation on the blood cells. The enzymatic activity of alanine aminotransferase (ALT), aspartate aminotransferase (AST), gamma-glutamyltranspeptidase (GGT), and serum concentrations of total, direct and indirect bilirubin, urea and creatinine were determined using a Doles ${ }^{\circledR}$ commercial kit (Doles Ltda., Goiânia, Goiás, Brazil) and absorbances were measured using a Bioplus $2000^{\circledR}$ semi-automated spectrophotometer (Bioplus Ltda., Barueri, São Paulo, Brazil).

\section{Genomic DNA extraction and PCR for hemoplasmas.}

A portion of the whole blood of each animal was kept at $-20{ }^{\circ} \mathrm{C}$ and the genomic DNA was extracted using a commercial kit (QlAamp DNA MiniKit; Qiagen ${ }^{\mathrm{TM}}$, Valencia, California, USA), following the protocol recommended by the manufacturer. After the extraction, the DNA was maintained at $-20{ }^{\circ} \mathrm{C}$ until the PCR assays.

\section{PCR to $M$. haemofelis and ' $C a$. M. haemominutum'}

To amplify 170 and $190 \mathrm{bp}$ partial sequences of $M$. haemofelis and ' $\mathrm{Ca}$. M. haemominutum', respectively, from the $16 \mathrm{~S}$ rRNA gene, PCR screening of all samples was performed with $5 \mu \mathrm{L}$ of template DNA in $25 \mu \mathrm{L}$ reaction mixtures containing 10X PCR buffer, $3.5 \mathrm{mM}$ of $\mathrm{MgCl}_{2}, 1.0 \mathrm{mM}$ of each deoxynucleotide triphosphate (dNTP), $1.25 \mathrm{U}$ of Taq DNA polymerase (Invitrogen $^{\mathrm{TM}}$, Carlsbad, California, USA) and $0.625 \mu \mathrm{M}$ of the primers (forward 5'-ACGAAAGTCTGATGGAGCAATA-3' and reverse 5'-ACGCCCAATAAATCC GRATAAT -3'), as described elsewhere (KEWISH et al., 2004) with modifications. The cycling conditions consisted of initial denaturation of $2 \mathrm{~min}$ at $94^{\circ} \mathrm{C}$, followed by 45 cycles of $94^{\circ} \mathrm{C}$ for $1 \mathrm{~min}, 60^{\circ} \mathrm{C}$ for $1 \mathrm{~min}, 72^{\circ} \mathrm{C}$ for $30 \mathrm{~s}$ and a final elongation step for $5 \mathrm{~min}$. For the positive samples, additional specific PCR tests were carried out for $M$. haemofelis and ' $C a$. M. haemominutum', as follows.

To amplify a 393bp partial sequence of $M$. haemofelis from the $16 \mathrm{~S}$ rRNA gene, PCR was performed with $5 \mu \mathrm{L}$ of template DNA in $25 \mu \mathrm{L}$ reaction mixtures containing 10X PCR buffer, $1.0 \mathrm{mM}$ of $\mathrm{MgCl}_{2}, 0.2 \mathrm{mM}$ of each dNTP, $1.5 \mathrm{U}$ of Taq DNA polymerase (Invitrogen $^{\mathrm{TM}}$, Carlsbad, California, USA) and $0.2 \mu \mathrm{M}$ of the primers ( $H$. felis F1 5'- GACTTTGGTTTCGGCCAAGG-3' and $H$. felis R3 5'- CGAAGTACTATCATAATTATCCCTC-3'), as described elsewhere (BERENT et al., 1998). The cycling conditions consisted of initial denaturation of $10 \mathrm{~min}$ at $94^{\circ} \mathrm{C}$ followed by 35 cycles of $94^{\circ} \mathrm{C}$ for $45 \mathrm{~s}, 54^{\circ} \mathrm{C}$ for $45 \mathrm{~s}, 72^{\circ} \mathrm{C}$ for $1 \mathrm{~min}$ and a final elongation step for $7 \mathrm{~min}$. For ' $\mathrm{Ca}$. M. haemominutum', the PCR was performed using the primers $1183 \mathrm{~F}$ (5'-GCATAATGTGTCGCAATC-3') and 1290R (5'- GTTTCAACTAGTACTTTCTCC C-3'), which amplify a $130 \mathrm{bp}$ sequence from the $16 \mathrm{~S}$ rRNA gene (FOLEY et al., 1998). The cycling conditions consisted of an initial denaturation of
$4 \mathrm{~min}$ at $94^{\circ} \mathrm{C}$, followed by 35 cycles of $94^{\circ} \mathrm{C}$ for $30 \mathrm{~s}, 53{ }^{\circ} \mathrm{C}$ for $1 \mathrm{~min}, 72^{\circ} \mathrm{C}$ for $45 \mathrm{~s}$ and a final elongation step for $5 \mathrm{~min}$.

All the positive samples on Kewish's protocol were positive on Berents' protocol (M. haemofelis) and/or Foley' protocol ('Ca. M. haemominutum').

\section{PCR to 'Ca. M. turicensis'}

To amplify a $400 \mathrm{bp}$ partial sequence of ' $\mathrm{Ca}$. M. turicensis' from the 16S rRNA gene, PCR of all samples was performed with $5 \mu \mathrm{L}$ of template DNA in $25 \mu \mathrm{L}$ reaction mixtures containing 10X PCR buffer, $1.5 \mathrm{mM}$ of $\mathrm{MgCl}_{2}, 0.2 \mathrm{mM}$ of each dNTP, $1.25 \mathrm{U}$ of Taq DNA polymerase (Invitrogen ${ }^{\mathrm{TM}}$, Carlsbad, California, USA) and $0.16 \mu \mathrm{M}$ of the primers (MT1-Fw 5'-GTATCCTCCATCAGACAGAA-3' and Mt2-Rv5'-CGCTCCATATTTAATTCCAA-3'). The cycling conditions consisted of initial denaturation of $10 \mathrm{~min}$ at $94^{\circ} \mathrm{C}$ for $45 \mathrm{~s}, 54^{\circ} \mathrm{C}$ for $45 \mathrm{~s}, 72^{\circ} \mathrm{C}$ for $1 \mathrm{~min}$ and a final elongation step for $7 \mathrm{~min}$ (SANTOS et al., 2009).

The positive control DNA samples of $M$. haemofelis (KF970934), 'Ca. M. haemominutum' (KF970932) and 'Ca. M. turicensis' (KJ095699) were used (ANDRÉ et al., 2014). Ultrapure sterile water was used as the negative control. To prevent PCR contamination, DNA extraction, reaction setup, PCR amplification and electrophoresis were performed in separate rooms.

\section{PCR to GAPDH (glyceraldehyde-3-phosphate dehydrogenase)}

To verify DNA integrity and absence of potential inhibitors, negative samples were submitted to PCR for detection of the GAPDH enzyme gene using primers developed by Birkenheuer et al. (2003). The reactions used the final volume of $25 \mu \mathrm{L}$, composed of $5 \mu \mathrm{L}$ of genomic DNA, 10x reaction buffer, $2.0 \mathrm{mM} \mathrm{MgCl}$, $0.2 \mathrm{mM}$ of each dNTP, $0.4 \mu \mathrm{M}$ of each primer (GAPDH F 5'-CCTTCATTGACCTCAACT ACAT-3' and GAPDH R 5'-CCAAAGTTGTCATGGATGACC-3'), 1.25 U of Taq polymerase, and ultrapure water until the final volume was achieved. The used amplification protocol consisted of initial denaturation at $95^{\circ} \mathrm{C}$ for 5 minutes, followed by 40 cycles of $94^{\circ} \mathrm{C}$ for 30 seconds for denaturation, annealing at $52{ }^{\circ} \mathrm{C}$ for 1 minute and extension at $72{ }^{\circ} \mathrm{C}$ for 1 minute, with final extension at $72{ }^{\circ} \mathrm{C}$ for 5 minutes according to Birkenheuer et al. (2003), with modifications.

The amplified products were analyzed by means of electrophoresis on $1.5 \%$ agarose gel in Tris-acetate-EDTA buffer ( $40 \mathrm{mMTris}$-acetate and $1 \mathrm{mM}$ EDTA), containing $0.5 \mathrm{mg} \cdot \mathrm{mL}^{-1}$ of ethidium bromide, with an output of $80 \mathrm{~V}$ and amperage of $180 \mathrm{mV}$ over a time of 35 minutes in an electrophoresis tank (Loccus Biotechnology ${ }^{\circledR}$, Cotia, São Paulo, Brazil). To determine the size of the amplified products, a $100 \mathrm{bp}$ molecular weight marker was used (Invitrogen ${ }^{\mathrm{TM}}$, Carlsbad, California, USA).

\section{Sequencing}

In approximately $15 \%$ of the positive samples a new PCR assay was performed for the sequencing of the same. Positive samples for $M$. haemofelis and 'Ca. M. haemominutum' were subjected to a PCR for the $16 \mathrm{~S}$ rRNA gene, whose primer oligonucleotides (HBT-F-5'-ATACGGCCCATATTCCTACG-3'; 
HBT-R-5'-TGCTC CACCACTTGTTCA-3 ') to amplify a 600 bp fragment (CRIADO-FORNELIO et al., 2003), whereas for ' $\mathrm{Ca}$. M. turicensis' the same protocol described in item 2.4.2 was used.

The reaction products were purified using Silica Bead DNA Gel Extraction Kit (Fermentas, Sáo Paulo, SP, Brazil). Purified amplified DNA fragments from positive samples were subjected to Sanger sequencing (SANGER et al., 1977) for confirmation in an automatic sequencer (ABI Prism 310 Genetic Analyser Applied Byosystem/ Perkin Elmer) at the at the Biological and Genome Biology Resource Center (CREBIO), UNESP/Jaboticabal. The electropherograms generated after the sequencing were evaluated by observing the quality of the peaks corresponding to each sequenced base, through the programs FinchTV 1.4.0 e Phred/Phrap/Consed (GORDON et al., 1998; EWING \& GREEN, 1998; EWING et al., 1998). The latter was also used to obtain the consensus sequences. In addition, the programs Bioedit v. 7.0.5.3 (HALL, 1999) e BLAST (ALTSCHUL et al., 1990) were used to compare the sequences obtained with others previously deposited in GenBank.

\section{Serological tests and nested PCR for detection of FIV and FeLV retroviruses}

We tested the serum samples through commercial immunochromatography tests for FIV and FeLV (Ag test kit; Alere ${ }^{\circledR}$ ), following the manufacturer's recommendations. Nested PCR tests were performed using protocols adapted (Taq polymerase increased to 1.25) from Marçola (2011) and Guimarães et al. (2009). Positive controls for FIV and FeLV were provided of the Department of Microbiology and Immunology, Institute of Bioscience of Botucatu, UNESP, Botucatu, São Paulo, Brazil. The animals with positive serological tests and/or nested PCR reactions were considered to be positive for FIV or FeLV.

\section{Statistical analysis}

The complete blood count (CBC) and serum biochemical test results from the animals that were positive and negative for hemoplasmas were submitted to the Kolmogorov-Smirnov test to confirmation of normality and after, were compared using Student's t test, with a 95\% confidence interval. The presence or absence of anemia ( $\mathrm{PCV}<24 \%$ ) was also evaluated in relation to the different hemoplasmas, by means of the chi-square test with Yates correction.

To determine the factors associated with positivity for each hemoplasma, the data from the structured interviews were tabulated in the Epi Info 3.5.1 statistical package. Spearman's correlation was applied to the variables in order to determine collinearity $(\mathrm{p}<0.8)$, using the Bioestat $5.0^{\circledR}$ statistical software (Table 1). Lastly, multivariate analysis using unconditional logistic regression was conducted, and the final model was built through introducing and withdrawing the different variables (backwards system).

\section{Results}

The frequency of infection by hemotropic mycoplasmas was 35.5\% (71/200): 19\% (38/200) of the animals were positive for 'Ca. M. haemominutum', 15.5\% (31/200) for M. haemofelis and $9 \%$ (18/200) for ' $C a$. M. turicensis'. Isolated infections were observed in $12.5 \%$ (25/200) for ' $C a$. M. haemominutum', $12 \%$ (24/200) for M. haemofelis and 3\% (6/200) for ' $C a$. M. turicensis'. Regarding copositivity, $2 \%$ (4/200) of the animals were positive for $M$. haemofelis and 'Ca. M. haemominutum', 1.5\% (3/200) for $M$. haemofelis and ' $C a$. M. turicensis', and 4.5\% (9/200) for ' $C a$. M. haemominutum' and ' $C a$. M. turicensis'. No animal showed positivity for the three agents at the same time (Figure 1). All samples negative for hemoplasmas were positive in GAPDH.

Sequencing and Blast analysis confirmed the identity of 16S rRNA amplicons for $M$. haemofelis in three samples, ' $C a$. M. haemominutum' in eight samples, and ' $C a$. M. turicensis' in one sample. The obtained sequences showed $100 \%$ identity to $M$. haemofelis previously deposited in GenBank (KM275246; KM275247), 100\% to 'Ca. M. turicensis' (JQ689950), and 95 to $100 \%$ identity to ' $\mathrm{Ca}$. M. haemominutum' sequences available in the referred database (KR905451; KR905457; KM275256; JQ689948).

The $\mathrm{CBC}$ and the serum biochemical tests showed that there was no statistically significant difference between the groups that were positive and negative for hemoplasmas $(\mathrm{p}>0.05)$. No association was found between anemia and positivity for the different agents ( $p>0.05)$, since anemia was detected only in four positive animals (two with 'Ca.M. haemominutum', one with M. haemofelis and one with 'Ca.M. turicensis', and none of them presented any clinical signs.

Regarding copositivity with retroviruses, three animals were positive for FIV and hemoplasmas (two copositive for $M$. haemofelis

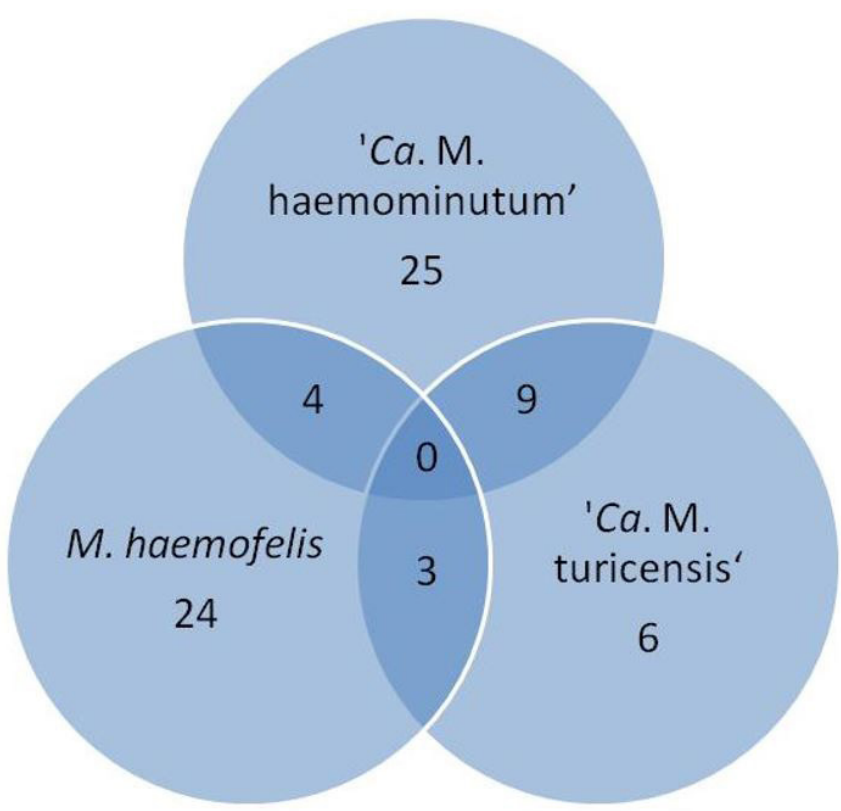

Figure 1. Venn diagram with the frequency of hemoplasmas infections in owned cats in the microregion of Ilhéus-Itabuna, Bahia, Brazil. 
and ' $C a$. M. haemominutum' and one for M. haemofelis), and three for FeLV (one copositive for $M$. haemofelis and ' $C a$. M. haemominutum', one for ' $\mathrm{Ca}$. M. haemominutum' and one for ' $\mathrm{Ca}$. M. turicensis'). None of the animals coinfected with retroviruses and hemoplasmas showed anemia or other laboratory abnormalities.

Unconditional logistic regression showed that the periurban region was a risk factor associated with positivity for $M$. haemofelis, while contact with other cats and infection by ' $\mathrm{C}$ a. M. turicensis' were associated with positivity for ' $C a$. M. haemominutum' (Table 2).

\section{Discussion}

The high prevalence of hemoplasmosis agents found in our study demonstrates ease of dissemination and exposure of cats to hemoplasmas. The region studied has the typically hot and humid weather present almost throughout the year. This climate is conducive to wards expansion of the presence of arthropods, along with promotion of constant contact among cats. The positive influence of the climate on the prevalence of these agents was mentioned by Santos et al. (2014), while low prevalences were observed in temperate regions (WILLI et al., 2006a) or dry regions (MICELI et al., 2013). Although there is no confirmation of arthropod transmission to date (WOODS et al., 2005), some observational studies support this possibility (LAPPIN et al., 2006; KAMRANI et al., 2008), which could partly explained our results.

The criteria used for animal selection in different studies have a major influence on the observed prevalence of hemoplasmas, and therefore caution is needed in comparing the results. Our animals were selected for convenience, without predilection for sex, breed and age, at different locations in the municipality

Table 1. Factors assessed using bivariate analysis in order to evaluate association with hemoplasmas infections in owned cats in the microregion of Ilhéus-Itabuna, Bahia, Brazil.

\begin{tabular}{|c|c|c|c|c|c|c|c|c|c|c|}
\hline \multirow{2}{*}{ Variables } & \multirow{2}{*}{ Categories } & \multicolumn{3}{|c|}{ Mycoplasma haemofelis } & \multicolumn{3}{|c|}{ 'Candidatus M. haemominutum' } & \multicolumn{3}{|c|}{ 'Candidatus M. turicensis' } \\
\hline & & Positive (\%) & Negative (\%) & $p$ & Positive (\%) & Negative (\%) & $p$ & Positive (\%) & Negative (\%) & $p$ \\
\hline \multirow[t]{2}{*}{ Age } & Up to1 year & $9(18.37)$ & $40(81.63)$ & 0.68 & $6(12.24)$ & $43(87.76)$ & 0.24 & $3(6.12)$ & $46(93.88)$ & 0.60 \\
\hline & $>1$ year & $22(14.57)$ & $129(85.43)$ & & $32(21.19)$ & $119(78.81)$ & & $15(9.93)$ & $136(90.07)$ & \\
\hline \multirow[t]{2}{*}{ Gender } & Male & $19(17.92)$ & $87(82.08)$ & 0.42 & $23(21.70)$ & $83(78.30)$ & 0.39 & $8(7.55)$ & $98(92.45)$ & 0.61 \\
\hline & Female & $12(12.77)$ & $82(87.23)$ & & $15(15.96)$ & $79(84.31)$ & & $10(10.64)$ & $84(89.36)$ & \\
\hline \multirow[t]{2}{*}{ Purebreed } & Yes & $1(8.33)$ & $11(91.67)$ & 0.77 & $3(25.00)$ & $9(75.00)$ & 0.87 & $0(0.00)$ & $12(100)$ & 0.60 \\
\hline & No & $30(15.96)$ & $158(84.04)$ & & $35(18.62)$ & $153(81.38)$ & & $18(9.57)$ & $170(90.43)$ & \\
\hline \multirow[t]{2}{*}{ Castrated } & Yes & $5(11.11)$ & $40(88.89)$ & 0.49 & $8(17.78)$ & $37(82.22)$ & 0.98 & $7(15.56)$ & 38 (84.44) & 0.15 \\
\hline & No & $26(16.77)$ & $129(83.23)$ & & $30(19.35)$ & $125(80.65)$ & & $11(7.10)$ & 144 (92.90) & \\
\hline \multirow[t]{2}{*}{ Fighting } & Yes & $9(12.33)$ & $64(87.67)$ & 0.46 & $13(17.81)$ & $60(82.19)$ & 0.89 & $7(9.59)$ & $66(90.41)$ & 0.97 \\
\hline & No & $22(17.32)$ & $105(82.68)$ & & $25(19.69)$ & $102(80.31)$ & & $11(8.66)$ & $116(91.34)$ & \\
\hline \multirow[t]{2}{*}{ Fleas } & Yes & $18(15,79)$ & $96(84.12)$ & 0.91 & $22(19.30)$ & $92(80.70)$ & 0.96 & $11(9.65)$ & $103(90.35)$ & 0.83 \\
\hline & No & $11(14.10)$ & $67(85.90)$ & & $14(17.95)$ & $64(82.05)$ & & $6(7.69)$ & $72(92.31)$ & \\
\hline \multirow{2}{*}{$\begin{array}{l}\text { Lives in } \\
\text { apartment }\end{array}$} & Yes & $2(18.18)$ & $9(81.82)$ & 0.86 & $4(36.36)$ & $7(63.64)$ & 0.26 & $3(27.27)$ & $8(72.73)$ & 0.06 \\
\hline & No & $29(15.34)$ & $160(84.66)$ & & 34 (17.99) & $155(82.01)$ & & $15(7.94)$ & $174(92.06)$ & \\
\hline \multirow[t]{2}{*}{ Housing } & Indoors & $12(18.46)$ & $53(81.54)$ & 0.55 & $11(16.92)$ & $54(83.08)$ & 0.74 & $7(10.77)$ & $58(89.23)$ & 0.73 \\
\hline & Outdoors & $19(14.07)$ & $116(85.93)$ & & $27(20.00)$ & $108(80.00)$ & & $11(8.15)$ & $124(91.85)$ & \\
\hline \multirow{2}{*}{$\begin{array}{l}\text { Lives on } \\
\text { periurban } \\
\text { area }\end{array}$} & Yes & $16(25.00)$ & $48(75.00)$ & 0.02 & $12(18.75)$ & $52(81.25)$ & 0.90 & $3(4.69)$ & $61(95.31)$ & 0.19 \\
\hline & No & $15(11.03)$ & $121(88.97)$ & & $26(19.12)$ & $110(80.88)$ & & $15(11.03)$ & $121(88.97)$ & \\
\hline \multirow{2}{*}{$\begin{array}{l}\text { Contact } \\
\text { with other } \\
\text { cats }\end{array}$} & Yes & $17(15.18)$ & $95(84.82)$ & 0.96 & $27(24.11)$ & $85(75.89)$ & 0.06 & $10(8.93)$ & 102 (91.07) & 0.83 \\
\hline & No & $14(15.91)$ & 74 (84.09) & & $11(12.50)$ & $77(87.50)$ & & $8(9.09)$ & $80(90.91)$ & \\
\hline \multirow[t]{2}{*}{ FIV+ } & Yes & $3(25.00)$ & $9(75.00)$ & 0.40 & $2(16.67)$ & $10(83.33)$ & 1.00 & $0(0.00)$ & $12(100)$ & 0.61 \\
\hline & No & $28(14.89)$ & $160(85.11)$ & & $36(19.15)$ & $152(80.85)$ & & $18(9.57)$ & $170(90.43)$ & \\
\hline \multirow[t]{2}{*}{ FeLV+ } & Yes & $1(16.67)$ & $5(83.33)$ & 1.00 & $2(33.33)$ & $4(66.67)$ & 0.32 & $1(16.67)$ & $5(83.33)$ & 0.44 \\
\hline & No & $30(15.46)$ & $164(84.54)$ & & $36(18.56)$ & $158(81.44)$ & & $17(8.76)$ & $177(91.24)$ & \\
\hline
\end{tabular}

Table 2. Final model of non-conditional logistic regression of factors associated with 'Candidatus M. haemominutum' and Mycoplasma haemofelis infection in owned cats in the microregion of Ilhéus-Itabuna, Bahia, Brazil.

\begin{tabular}{ccccc}
\hline Agents & Variables & Odds ratio & CI (95\%) & P value \\
\hline 'Candidatus M. haemominutum'* & Contact with other cats & 2.62 & $1.12-6.10$ & 0.026 \\
Mycoplasma haemofelis ${ }^{* *}$ & Coinfection with 'C . M. turicensis' & 5.12 & $1.76-14.9$ & 0.003 \\
\hline
\end{tabular}

${ }^{*} p<0.00005$, likelihood $=168.59 ;{ }^{* *} p<0.0109$, likelihood $=166.40$. 
(urban and periurban area), but only healthy animals on physical examination were recruited (to allow some extrapolation for the region). Higher prevalence of $M$. haemofelis is usually found in studies in which the animals selected are sick (e.g. samples from animals treated in veterinary establishments), regardless of the presence or absence of regenerative anemia (JENSEN et al. 2001; KEWISH et al. 2004; GHAZISAEEDI et al., 2014). On the other hand, when the selection criteria call for healthy animals, infection by ' $\mathrm{Ca}$. M. haemominutum' is found to be the most prevalent type (INOKUMA et al., 2004; FUJIHARA et al., 2007; MACIEIRA et al., 2008), which corroborates our results, since only healthy animals were selected in our study.

The higher prevalence of ' $\mathrm{Ca}$. M. haemominutum' than of other hemoplasmas has similarly been found in different parts of the world, as well as in all regions of Brazil (BRAGA et al., 2012; DE BORTOLI et al., 2012; MICELI et al., 2013; SANTOS et al. 2014; SANTIS et al., 2014). It may be linked to different forms of transmission for this agent or to its low potential for causing illness and death of the host, such that its low pathogenicity would not prevent socialization with other cats, thus encouraging contact between infected and uninfected cats (TANAHARA et al., 2010). Moreover, this species of hemoplasma has been seen to maintain persistent infections for a longer time than have other feline hemoplasmas (BARKER \& TASKER, 2013), which facilitates its transmission.

In our study, a significant number of animals infected only by 'Ca.M. turicensis' was observed. This finding is unusual among the accounts described in the literature (PETERS et al., 2008; BRAGA et al., 2012; GHAZISAEEDI et al., 2014), since the presence of ' $\mathrm{Ca}$. M. turicensis' has generally been associated with other species of hemoplasmas (WILLI et al., 2006a, b; FUJIHARA et al., 2007; WILLI et al., 2007b; MICELI et al., 2013; SANTIS et al., 2014).

Although ' $C a$. M. haemominutum' and $M$. haemofelis showed the highest prevalences, the rate of coinfection between them was low. In the literature, low prevalence of coinfection between these two agents is commonly reported (JENSEN et al., 2001; TASKER et al., 2003, 2004; MACIEIRA et al., 2008; MICELI et al., 2013; SANTOS et al., 2014), which corroborates our findings and may indicate differences in transmission mechanisms between these agents. This hypothesis is reinforced by some studies that have not demonstrated the presence of coinfection (KEWISH et al., 2004; INOKUMA et al., 2004). Sixty-seven percent (12/18) of the cats positive for ' $C a$. M. turicensis' showed copositivity, mainly with 'Ca. M. haemominutum', which reinforces the hypothesis that these two agents have common routes of infection or risk factors (WILLI et al., 2006a; WILLI et al., 2007b; FUJIHARA et al., 2007). Moreover, this shows that cross-protection between them is probably absent (WILLI et al., 2006b; FUJIHARA et al., 2007).

In this context, the agents may have similar forms of transmission, but with different effectiveness, or even different transmission mechanisms. Thus, we chose to determine the factors individually associated, according to the hemoplasma species (FOLEY et al., 1998; TASKER et al., 2004), and not all in a single group.

Contact with other cats was noted as a risk factor for transmission of 'Ca. M. haemominutum'. The possibility of transmission through water, food and mutual grooming has been suggested because these microorganisms, along with ' $C a$. M. turicensis', have been found in cats' saliva (WILLI et al., 2005; WILLI et al., 2007a). Nonetheless, it has been found that aggressive interactions among animals with contaminated blood is the only way that efficient transmission of hemoplasmas can be ensured (MUSEUX et al., 2009; WILLI et al., 2007b). Finally, "prosperous coexistence of cats and microorganisms", as characterized by Tanahara et al. (2010), keeps cats infected by ' $C a$. M. haemominutum' healthy and in close contact with uninfected animals, which can partly explain the prevalences found.

The presence of the periurban area as a risk factor for positivity for $M$. haemofelis initially made us think that the animals in our study that were living in this area had more access to the streets than did those in the urban area. However, this hypothesis was not confirmed, since the percentages of cats in the two areas (urban and periurban) with access to the street was similar. The heterogeneous distribution of this hemoplasma in this region may, in fact, have been an intrinsic feature of the study area, and might relate to special care within the epidemiology of hemotropic mycoplasmosis, or to the choice of areas or collection points that comprised the study.

Older age was not a factor associated with positivity for hemoplasmas. Nevertheless, while the positivity for ' $\mathrm{Ca}$. M. haemominutum' and 'Ca. M. turicensis' proved to be higher, although not statistically significant, in older animals, the opposite was observed regarding positivity for $M$. haemofelis, since the population of young animals (less than one year of age) showed the highest number of positive animals. Similar results have also been described in the literature (TASKER et al., 2003, 2004; SYKES et al., 2008) and indicate that, in animals positive for $M$. haemofelis, this agent leads to infection early on. This suggests that different transmission routes for infection exist among hemoplasmas. Although this capacity for early infection has not yet been proven, it could be due to transplacental or horizontal transmission between the kitten and its mother (HARVEY \& GADKIN, 1977). On the other hand, the greater presence of ' $\mathrm{Ca}$. M. haemominutum' in old animals may be associated with persistent long-term infection (SYKES et al., 2008).

The results relating to the influence of hemoplasmosis agents as inducers of anemia are conflicting (JENSEN et al., 2001; GHAZISAEEDI et al., 2014; KEWISH et al., 2004; MACIEIRA et al., 2008; WILLI et al., 2006a). In our study, no hematological differences were observed between positive and negative groups, even in young or coinfected animals (data not show), which reassumed to be more susceptible groups (WILLI et al., 2006b; TASKER et al., 2009; GHAZISAEEDI et al., 2014). These results may be associated with the stage of hemoplasmas infection in animals, host-parasite relationship (MACIEIRA et al., 2008), and presence of low pathogenic strains in the region (FOLEY et al., 1998).

No association between retroviruses and hemoplasmas could be observed, differing from the results of Macieira et al. (2008), Sykes et al. (2008) and Harrus et al. (2002). In our study, the few animals that were positive for both retroviruses and hemoplasmas did not show abnormalities in the $\mathrm{CBC}$ and serum biochemical tests, thus suggesting that there was an absence of synergism in cases of coinfection, probably because the animals were not yet 
immunocompromised (LACERDA et al., 2017). Willi et al. (2006a) stated that the presence of retroviruses alone would not be enough for clinical manifestation of hemoplasmosis. Therefore, the development of an immunosuppressive condition caused by the virus or an interaction between retroviruses and progenitor cells would be necessary for the manifestation of hemotrophic mycoplasmosis. These findings could explain the small number of cats coinfected by hemoplasmas and retroviruses with clinical disease in cross-sectional studies (MARCONDES et al., 2018).

This study indicates that the presence of agents of feline hemotropic mycoplasmosis is common in northeastern Brazil. The results are consistent with those from most other studies conducted in other regions of Brazil (DE BORTOLI et al., 2012; BRAGA et al., 2012; SANTOS et al., 2014; SANTIS et al., 2014). We believe that further longitudinal or cross-sectional studies are important for elucidating issues relating to the epidemiology of the agents and to interactions between hemoplasma species and other common cat diseases.

\section{Acknowledgements}

We would like to thank Prof. Dr. João Pessoa Araújo Júnior of the Department of Microbiology and Immunology, Institute of Bioscience of Botucatu, UNESP-Botucatu, São Paulo, Brazil, for kindly supplied DNA positive controls for FIV and FeLV.

\section{References}

Altschul SF, Gish W, Miller W, Myers EW, Lipman DJ. Basic local alignment search tool. J Mol Biol 1990; 215(3): 403-410. http://dx.doi. org/10.1016/S0022-2836(05)80360-2. PMid:2231712.

André MR, Baccarim Denardi NC, Marques de Sousa KC, Gonçalves LR, Henrique PC, Grosse Rossi Ontivero CR, et al. Arthropod-borne pathogens circulating in free-roaming domestic cats in a zoo environment in Brazil. Ticks Tick Borne Dis 2014; 5(5): 545-551. http://dx.doi. org/10.1016/j.ttbdis.2014.03.011. PMid:24889035.

Barker E, Tasker S. Haemoplasmas: Lessons learnt from cats. $N Z$ Vet J 2013; 61(4): 184-192. http://dx.doi.org/10.1080/00480169.2013.77 1760. PMid:23458414.

Berent LM, Messick JB, Cooper SK. Detection of Haemobartonella felis in cats with experimentally induced acute and chronic infections, using a polymerase chain reaction assay. Am J Vet Res 1998; 59(10): 1215-1220. PMid:9781450.

Birkenheuer AJ, Levy MG, Breitschwerdt EB. Development and evaluation of a seminested PCR for detection and differentiation of Babesia gibsoni (Asian Genotype) and B. canis DNA in canine blood samples. J Clin Microbiol 2003; 41(9): 4172-4177. http://dx.doi.org/10.1128/ JCM.41.9.4172-4177.2003. PMid:12958243.

Braga MS, André MR, Freschi CR, Teixeira MC, Machado RZ. Molecular detection of hemoplasma infection among cats from São Luís Island, Maranhão, Brazil. BrazJ Microbiol 2012; 43(2): 569-575. http://dx.doi. org/10.1590/S1517-83822012000200018. PMid:24031865.

Collado VM, Domenech A, Miró G, Martin S, Escolar E, Gomez-Lucia E. Epidemiological aspects and clinicopathological findings in cats naturally infected with Feline Leukemia Virus (FeLV) and/or Feline
Immunodeficiency Virus (FIV). Open J Vet Med 2012; 2(1): 13-20. http://dx.doi.org/10.4236/ojvm.2012.21003.

Criado-Fornelio A, Martinez-Marcos A, Buling-Saraña A, Barba-Carretero JC. Presence of Mycoplasma haemofelis, Mycoplasma haemominutum and piroplasmids in cats from southern Europe: a molecular study. Vet Microbiol 2003; 93(4): 307-317. http://dx.doi.org/10.1016/S03781135(03)00044-0. PMid:12713893.

De Bortoli CP, André MR, Seki MC, Pinto AA, Machado ST, Machado RZ. Detection of hemoplasma and Bartonella species and co-infection with retroviruses in cats subjected to a spaying/neutering program in Jaboticabal, SP, Brazil. Rev Bras Parasitol Vet 2012; 21(3): 219-223. http:// dx.doi.org/10.1590/S1984-29612012000300008. PMid:23070430.

Ewing B, Green P. Base-calling of automated sequencer traces using Phred. II. Error probabilities. Genome Res 1998; 8(3): 186-194. http:// dx.doi.org/10.1101/gr.8.3.186. PMid:9521922.

Ewing B, Hillier L, Wendl MC, Green P. Base-calling of automated sequencer traces using Phred. I. Acuracy Assessement. Genome Res 1998; 8(3): 175-185. http://dx.doi.org/10.1101/gr.8.3.175. PMid:9521921.

Foley JE, Harrus S, Poland A, Chomel B, Pedersen NC. Molecular, clinical, and pathologic comparison of two distinct strains of Haemobartonella felis in domestic cats. Am J Vet Res 1998; 59(12): 1581-1588. PMid:9858411.

Fujihara M, Watanabe M, Yamada T, Harasawa R. Occurrence of 'Candidatus Mycoplasma turicensis' infection in domestic cats in Japan. J Vet Med Sci 2007; 69(10): 1061-1063. http://dx.doi.org/10.1292/ jvms.69.1061. PMid:17984594.

Ghazisaeedi F, Atyabi N, Zahrai Salehi T, Gentilini F, Ashrafi Tamai I, Akbarein H, et al. A molecular study of hemotropic mycoplasmas (hemoplasmas) in cats in Iran. Vet Clin Pathol 2014; 43(3): 381-386. http://dx.doi.org/10.1111/vcp.12166. PMid:24948469.

Gordon D, Abajian C, Green P. Consed: a graphical tool for sequence finishing. Genome Res 1998; 8(3): 195-202. http://dx.doi.org/10.1101/ gr.8.3.195. PMid:9521923.

Greggs WM 3rd, Clouser CL, Patterson SE, Mansky LM. Broadening the use of antiretroviral therapy: the case for feline leukemia vírus. Ther Clin Risk Manag 2011; 7: 115-122. PMid:21479142.

Grindem CB, Corbett WT, Tomkins MT. Risk factors for Haemobartonella felis infection in cats. J Am Vet Med Assoc 1990; 196(1): 96-99. PMid:2295559.

Guimaraes AM, Brandão PE, Moraes W, Cubas ZS, Santos LC, Villarreal LY, et al. Survey of feline leukemia virus and feline coronaviruses in captive neotropical wild felids from Southern Brazil. J Zoo Wildl Med 2009; 40(2): 360-364. http://dx.doi.org/10.1638/2008-0067.1. PMid:19569487.

Hackett TB, Jensen WA, Lehman TL, Hohenhaus AE, Crawford PC, Giger U, et al. Prevalence of DNA of Mycoplasma haemofelis, 'Candidatus Mycoplasma haemominutum', Anaplasma phagocytophilum, and species of Bartonella, Neorickettsia, and Ehrlichia in cats used as blood donors in the United States. J Am Vet Med Assoc 2006; 229(5): 700-705. http:// dx.doi.org/10.2460/javma.229.5.700. PMid:16948578.

Hall TA. BioEdit: a user-friendly biological sequence alignment editor and analysis program for Windows 95/98/NT. Nucleic Acids Symp Ser 1999; 41: 95-98.

Harrus S, Klement E, Aroch I, Stein T, Bark H, Lavy E, et al. Retrospective study of 46 cases of feline haemobartonellosis in Israel and their relationships with FeLV and FIV infections. Vet Rec 2002; 151(3): 82-85. http://dx.doi. org/10.1136/vr.151.3.82. PMid:12164225. 
Harvey JW, Gadkin JM. Experimental feline haemobartonellosis. J Am Anim Hosp Assoc 1977; 13: 28-38.

Hornok S, Micsutka A, Meli ML, Lutz H, Hofmann-Lehmann R. Molecular investigation of transplacental and vector-borne transmission of bovine haemoplasmas. Vet Microbiol 2011; 152(3-4): 411-414. http:// dx.doi.org/10.1016/j.vetmic.2011.04.031. PMid:21605950.

Inokuma $\mathrm{H}$, Taroura $S$, Okuda M, Hisasue M, Itamoto K, Une S, et al. Molecular survey of Mycoplasma haemofelis and 'Candidatus Mycoplasma haemominutum' infection in cats in Yamaguchi and surrounding areas. J Vet Med Sci 2004; 66(8): 1017-1020. http://dx.doi.org/10.1292/ jvms.66.1017. PMid:15353861.

Jensen WA, Lappin MR, Kamkar S, Reagan WJ. Use of a polymerase chain reaction assay to detect and differentiate two strains of Haemobartonella felis in naturally infected cats. Am J Vet Res 2001; 62 (4): 604-608. http:// dx.doi.org/10.2460/ajvr.2001.62.604. PMid:11327472.

Kamrani A, Parreira VR, Greenwood J, Prescott JF. The prevalence of Bartonella, hemoplasma, and Rickettsia felis infections in domestic cats and in cat fleas in Ontario. Can J Vet Res 2008; 72(5): 411-419. PMid:19086373.

Kewish KE, Appleyard GD, Myers SL, Kidney BA, Jackson ML. Mycoplasma haemofelis and Mycoplasma haemominutum detection by polymerase chain reaction in cats from Saskatchewan and Alberta. Can Vet J 2004; 45(9): 749-752. PMid:15510683.

Lacerda LC, Silva AN, Freitas JS, Cruz RDS, Said RA, Munhoz AD. Feline immunodeficiency virus and feline leukemia virus: frequency and associated factors in cats in northeastern Brazil. Genet Mol Res 2017; 16(2): 1-8. http://dx.doi.org/10.4238/gmr16029633. PMid:28510253.

Lappin MR, Griffin B, Brunt J, Riley A, Burney D, Hawley JR, et al. Prevalence of Bartonella species, haemoplasma species, Ehrlichia species, Anaplasma phagocytophilum, and Neorickettsia risticii DNA in the blood of cats and their fleas in the United States. J Feline Med Surg 2006; 8(2): 85-90. http://dx.doi.org/10.1016/j.jfms.2005.08.003. PMid:16290092.

Macieira DB, Menezes RC, Damico CB, Almosny NR, McLane HL, Daggy JK, et al. Prevalence and risk factors for hemoplasmas in domestic cats naturally infected with feline immunodeficiency virus and/or feline leukemia virus in Rio de Janeiro - Brazil. J Feline Med Surg 2008; 10(2): 120-129. http://dx.doi.org/10.1016/j.jfms.2007.08.002. PMid:17905624.

Macieira DB, Menezes RCAA, Damico CB, Almosny NR, Messick JB. Use of Southern Blot/Hybridization technique associated to polymerase chain reaction to improve the sensitivity in the diagnosis of hemoplasma infections in domestic cats. Rev Bras Parasitol Vet 2009; 18(1 Supl): 1-6.. PMid:20040183.

Marçola TG. Estudo da avaliação laboratorial e ocorrência da infecção pelo vírus da imunodeficiência felina e co-infecçöes em felinos domésticos de diferentes localidades do Distrito Federal [dissertação]. Brasília: Universidade de Brasília; 2011.

Marcondes M, Hirata KY, Vides JP, Sobrinho LSV, Azevedo JS, Vieira TSWJ, et al. Infection by Mycoplasma spp., feline immunodeficiency virus and feline leukemia virus in cats from an area endemic for visceral leishmaniasis. Parasit Vectors 2018; 11(1): 131. http://dx.doi.org/10.1186/ s13071-018-2716-9. PMid:29554969.

Miceli NG, Gavioli FA, Gonçalves LR, André MR, Sousa VR, Sousa $\mathrm{KC}$, et al. Molecular detection of feline arthropod-borne pathogens in cats in Cuiabá, state of Mato Grosso, central-western region of Brazil. Rev Bras Parasitol Vet 2013; 22(3): 385-390. http://dx.doi.org/10.1590/ S1984-29612013000300011. PMid:24142170.
Museux K, Boretti FS, Willi B, Riond B, Hoelzle K, Hoelzle LE, et al. In vivo transmission studies of 'Candidatus Mycoplasma turicensis' in the domestic cat. Vet Res 2009; 40(5): 45. http://dx.doi.org/10.1051/ vetres/2009028. PMid:19505421.

Pentecost RL, Marsh AE, Niehaus AJ, Daleccio J, Daniels JB, RajalaSchultz PJ, et al. Vertical transmission of Mycoplasma haemolamae in alpacas (Vicugna pacos). Small Rumin Res 2012; 106(2): 181-188. http:// dx.doi.org/10.1016/j.smallrumres.2012.02.021.

Persichetti MF, Solano-Gallego L, Serrano L, Altet L, Reale S, Masucci $\mathrm{M}$, et al. Detection of vector-borne pathogens in cats and their ectoparasites in southern Italy. Parasit Vectors 2016; 9(1): 247. http://dx.doi.org/10.1186/ s13071-016-1534-1. PMid:27160725.

Peters IR, Helps CR, Willi B, Hofmann-Lehmann R, Tasker S. The prevalence of three species of feline haemoplasmas in samples submitted to a diagnostics service as determined by three novel real-time duplex PCR assays. Vet Microbiol 2008; 126(1-3): 142-150. http://dx.doi. org/10.1016/j.vetmic.2007.06.017. PMid:17689890.

Sanger F, Nicklen S, Coulson AR. DNA sequencing with chain-terminating inhibitors. Proc Natl Acad Sci USA 1977; 74(12): 5463-5467. http:// dx.doi.org/10.1073/pnas.74.12.5463. PMid:271968.

Santis ACGA, Herrera HM, Sousa KCM, Gonçalves LR, Denardi NCB, Domingos IH, et al. Molecular detection of hemotrophic mycoplasmas among domiciled and free-roaming cats in Campo Grande, state of Mato Grosso do Sul, Brazil. Rev Bras Parasitol Vet 2014; 23(2): 231-236. http:// dx.doi.org/10.1590/S1984-29612014039. PMid:25054503.

Santos AP, Conrado FO, Messick JB, Biondo AW, Oliveira ST, Guimarães AM, et al. Hemoplasma prevalence and hematological abnormalities associated with infection in three different cat populations from Southern Brazil. Rev Bras Parasitol Vet 2014; 23(4): 428-434. http://dx.doi. org/10.1590/S1984-29612014079. PMid:25517519.

Santos AP, Messick JB, Biondo AW, Oliveira ST, Pedralli V, Lasta CS, et al. Design, optimization, and application of a conventional PCR assay with an internal control for detection of 'Candidatus Mycoplasma turicensis' 16S rDNA in domestic cats from Brazil. Vet Clin Pathol 2009; 38(4): 443-452. http://dx.doi.org/10.1111/j.1939-165X.2009.00158.x. PMid:19548972.

Sykes JE, Drazenovich NL, Kyles AE, Ball LM, Leutenegger CM. Detection of Mixed Infections with "Candidatus Mycoplasma haemominutum" and Mycoplasma haemofelis Using Real-Time TaqMan Polymerase Chain Reaction. J Vet Diagn Invest 2007; 19(3): 250-255. http://dx.doi. org/10.1177/104063870701900304. PMid:17459853.

Sykes JE, Terry JC, Lindsay LL, Owens SD. Prevalences of various hemoplasma species among cats in the United States with possible hemoplasmosis. J Am Vet Med Assoc 2008; 232(3): 372-379. http:// dx.doi.org/10.2460/javma.232.3.372. PMid:18241101.

Tanahara M, Miyamoto S, Nishio T, Yoshii Y, Sakuma M, Sakata Y, et al. An Epidemiological Survey of Feline Hemoplasma Infection in Japan. J Vet Med Sci 2010; 72(12): 1575-1581. http://dx.doi.org/10.1292/ jvms.10-0143. PMid:20686353.

Tasker S, Binns SH, Day MJ, Gruffydd-Jones TJ, Harbour DA, Helps $\mathrm{CR}$, et al. Use of a PCR assay to assess the prevalence and risk factors for Mycoplasma haemofelis and 'Candidatus Mycoplasma haemominutum' in cats in the United Kingdom. Vet Rec 2003; 152(7): 193-198. http:// dx.doi.org/10.1136/vr.152.7.193. PMid:12620033.

Tasker S, Braddock JA, Baral R, Helps CR, Day MJ, Gruffydd-Jones TJ, et al. Diagnosis of feline haemoplasma infection in Australian cats 
using a real-time PCR assay. J Feline Med Surg 2004; 6(6): 345-354. http://dx.doi.org/10.1016/j.jfms.2003.12.003. PMid:15546766.

Tasker S, Peters IR, Papasouliotis K, Cue SM, Willi B, Hofmann-Lehmann $\mathrm{R}$, et al. Description of outcomes of experimental infection with feline haemoplasmas: copy numbers, haematology, Coombs' testing and blood glucose concentrations. Vet Microbiol 2009; 139(3-4): 323-332. http:// dx.doi.org/10.1016/j.vetmic.2009.06.028. PMid:19615832.

Tompkins MB, Nelson PD, English RV, Novotney C. Early events in the immunopathogenesis of feline retrovirus infections. J Am Vet Med Assoc 1991; 199(10): 1311-1315. PMid:1666073.

Willi B, Boretti FS, Baumgartner C, Tasker S, Wenger B, Cattori V, et al. Prevalence, risk factor analysis, and follow-up of infections caused by three feline hemoplasma species in cats in Switzerland. J Clin Microbiol 2006a; 44(3): 961-969. http://dx.doi.org/10.1128/JCM.44.3.961969.2006. PMid:16517884.

Willi B, Boretti FS, Cattori V, Tasker S, Meli ML, Reusch C, et al. Identification, molecular characterization, and experimental transmission of a new hemoplasma isolate from a cat with hemolytic anemia in Switzerland. J Clin Microbiol 2005; 43(6): 2581-2585. http://dx.doi. org/10.1128/JCM.43.6.2581-2585.2005. PMid:15956367.
Willi B, Boretti FS, Meli ML, Bernasconi MV, Casati S, Hegglin D, et al. Real-time PCR investigation of potential vectors, reservoirs and shedding patterns of feline hemotropic mycoplasmas. Appl Environ Microbiol 2007a; 73(12): 3798-3802. http://dx.doi.org/10.1128/AEM.02977-06. PMid:17468284.

Willi B, Boretti FS, Tasker S, Meli ML, Wengi N, Reusch CE, et al. From Haemobartonella to hemoplasma: Molecular methods provide new insights. Vet Microbiol 2007b; 125(3-4): 197-209. http://dx.doi. org/10.1016/j.vetmic.2007.06.027. PMid:17706380.

Willi B, Tasker S, Boretti FS, Doherr MG, Cattori V, Meli ML, et al. Phylogenetic analysis of "Candidatus Mycoplasma turicensis" isolates from Pet cats in the United Kingdom, Australia, and South Africa, with analysis of risk factors for infection. J Clin Microbiol 2006b; 44(12) 4430-4435. http://dx.doi.org/10.1128/JCM.00987-06. PMid:17035497.

Woods JE, Brewer MM, Hawley JR, Wisnewski N, Lappin MR. Evaluation of experimental transmission of 'Candidatus Mycoplasma haemominutum' and Mycoplasma haemofelis by Ctenocephalides felis to cats. Am J Vet Res 2005; 66(6): 1008-1012. http://dx.doi.org/10.2460/ ajvr.2005.66.1008. PMid:16008224. 